\title{
Molecular cytogenetic characterization of terminal $14 q 32$ deletions in two children with an abnormal phenotype and corpus callosum hypoplasia
}

\author{
Anouck Schneider ${ }^{1}$, Brigitte Benzacken ${ }^{2}$, Agnès Guichet ${ }^{3}$, Alain Verloes ${ }^{4}$, \\ Dominique Bonneau ${ }^{3}$, Nathalie Collot ${ }^{5}$, Florence Dastot-Le-Moal ${ }^{5}$, Michel Goossens ${ }^{5}$, \\ Laurence Taine ${ }^{6}$, Emilie Landais ${ }^{1}$, Dominique Gaillard ${ }^{1}$ and Martine Doco-Fenzy ${ }^{*, 1}$
}

${ }^{1}$ Service de Génétique, CHU, UFR de médecine, IFR53, Reims, France; ${ }^{2}$ Service d'Histologie-Embryologie-Cytogénétique,
AP-HP, Hôpital Jean Verdier, Bondy, France; ${ }^{3}$ Service de Génétique, CHU et INSERM U-694, Angers, France; ${ }^{4}$ Unité de
Génétique Clinique, AP-HP, Hôpital Robert Debré, Paris, France; ${ }^{5}$ Laboratoire de Biochimie Génétique, AP-HP, et
INSERM U-841, CHU Henri Mondor, Créteil, France; ${ }^{6}$ Service de Génétique Médicale, CHU Pellegrin, Bordeaux, France

Among previously reported cases of $14 q$ terminal deletions, only 11 have dealt with pure terminal deletion of 14q (14q3-14qter) and the break points were mapped by fluorescent in situ hybridisation (FISH) or genotyping in only four of them. Thanks to a collaborative study on behalf of the 'Association des Cytogeneticiens de langue Française'(ACLF), we report two patients with terminal deletion of the long arm of chromosome 14, del(14)(q32.2) and $\operatorname{del}(14)(q 32.32)$, diagnosed by subtelomere screening. In the two cases, a thick nuchal skinfold was detected by early ultrasound with normal prenatal karyotype. Their postnatal phenotype included large forehead, narrow palpebral fissures, epicanthic folds, upturned tip of the nose, narrow mouth and thin upper lip, microretrognathia, prominent earlobes, hypotonia, delayed psychomotor development and hypoplastic corpus callosum. By physical mapping using FISH, the size of the deletions was measured for patients 1 and $2: 6.55 \pm 1.05$ and $4.67 \pm 0.10 \mathrm{Mb}$, respectively. The paternal origin of the deleted chromosome 14 was established by genotyping of microsatellites for patient 1 and the phenotype of terminal $\operatorname{del}(14)(q 32)$ was compared to maternal uniparental disomy 14.

European Journal of Human Genetics (2008) 16, 680-687; doi:10.1038/sj.ejhg.5201977; published online 16 January 2008

Keywords: chromosome band 14q32; 14q telomere; terminal deletion; chromosome 14; corpus callosum

Introduction

Deletions of chromosome $14 \mathrm{q}$ are rarely reported. Excluding ring chromosome 14, about 30 previous articles have dealt with distal deletion of chromosome $14 \mathrm{q}^{1-21}$ of which only 22 cases affected the $14 \mathrm{q} 3$ region. Three of these cases involved autosomal translocations. ${ }^{2-4}$ In six

*Correspondence: $\operatorname{Dr} M$ Doco-Fenzy, Service de génétique, Hopital Maison-Blanche, 45 rue Cognacq-Jay, 51092 Reims Cedex, France.

Tel: + 33326788582 ; Fax: + 333267841 45;

E-mail: mdocofenzy@chu-reims.fr

Received 29 May 2007; revised 30 October 2007; accepted 15 November 2007; published online 16 January 2008 other cases, the deletion was associated with either a $20 p$ deletion $^{5}$ or a chromosome 14 rearrangement. ${ }^{6-10}$ In one case, the deletion appeared to be interstitial. ${ }^{11,12}$ In one case, the deletion was associated with mosaicism $(46, \mathrm{XX} /$ 46,XX,del(14)(q32.3)). ${ }^{13}$ Only 11 cases were considered as examples of pure, distal and homogeneous $14 \mathrm{q}$ arm deletions $^{12,14-21}$ (Table 1).

Most of the reported cases were cytogenetically visible and diagnosed by classical banding. Five cases were diagnosed only by subtelomere fluorescent in situ hybridisation (FISH). ${ }^{3,20,21}$ If we consider the case of Maurin et $a_{1}{ }^{10}$ a pure distal $14 \mathrm{q}$ deletion since the presence of a terminal NOR region should not have any influence on the 
Table 1 Published cases with $14 q 3$ terminal deletions

\begin{tabular}{|c|c|c|c|c|c|c|}
\hline $\begin{array}{l}\text { Chromosome } \\
14 \text { break } \\
\text { point }\end{array}$ & $\begin{array}{l}\text { Terminal deletion } \\
\text { associated with } \\
\text { another abnormal } \\
\text { segment or clone }\end{array}$ & $\begin{array}{l}\text { Pure } \\
\text { homogeneous } \\
\text { deletion }\end{array}$ & Karyotype & FISH & STS & $\begin{array}{l}\text { Deletion } \\
\text { size }\end{array}$ \\
\hline \multirow[t]{2}{*}{$14 q 31$} & Nielsen et $a l^{6}$ & & $\begin{array}{l}46, X X / 46, X X, \operatorname{inv}(14) \\
(q 21 \rightarrow q 31), \operatorname{del}(14)(q 31)\end{array}$ & - & - & $?$ \\
\hline & Uehara et $a P^{5}$ & & $\begin{array}{l}46, X X, \text { del }(14)(q 32) \text { del } \\
(20)(p 11)\end{array}$ & - & - & $?$ \\
\hline \multirow[t]{2}{*}{$14 q 32$} & Bregant et $a t^{4}$ & Fu Sun Yen et al & $\begin{array}{l}46, X X, \operatorname{del}(14)(q 31.1) \\
46, X Y, \operatorname{der}(14) \mathrm{t}(10 ; 14) \\
(q 24 ; q 32)\end{array}$ & - & - & $?$ \\
\hline & & Mertens et $a l^{18}$ & $46, X Y$, del $(14)(q 32)$ & - & - & $?$ \\
\hline $14 q 32.1$ & $\begin{array}{l}\text { Masada et } a l^{\prime} \\
\text { Magnani et } a l^{8}\end{array}$ & & $\begin{array}{l}46, X Y, \text { del }(14)(q 32.11 \rightarrow \text { qter }) \\
47, X X,+? \text { mar, del } \\
(14 q 32.1-\text { qter })\end{array}$ & - & - & $?$ \\
\hline $14 q 32.2$ & & Wang et $a l^{16}$ & $46, X X, \operatorname{del}(14 q 32.2)$ & - & - & $?$ \\
\hline \multirow[t]{5}{*}{$14 q 32.3$} & Miller et $a l^{13}$ & & $\begin{array}{l}46, X X / 46, X X \\
\text { del }(14)(q 32.3)\end{array}$ & - & - & $?$ \\
\hline & Meschede et $a l^{2}$ & & $45, X Y, \tan (14 ; 21)(q 32.3 ; p 11)$ & - & - & $?$ \\
\hline & Chen et $a P^{9}$ & & $\begin{array}{l}46, X X, \operatorname{der}(14)- \\
\operatorname{dup}(14)(q 32.3 q 31.3) \\
\operatorname{del}(14)\left(q^{32.3)}\right.\end{array}$ & - & - & $?$ \\
\hline & & Telford et $a l^{15}$ & $46, \mathrm{XX}, \operatorname{del}(14)(q 32.3)$ & - & - & $?$ \\
\hline & & $\begin{array}{l}\text { Wintle et al } \\
\text { (patient } \\
\text { HSC1363) }^{12}\end{array}$ & 46,XX, del(14)(pter $\rightarrow$ q32.3:) & $\begin{array}{l}\text { DIO3 }(101088- \\
101215 \mathrm{~kb}) \\
\text { deleted }\end{array}$ & $\begin{array}{l}\text { D14S13 (not } \\
\text { deleted) D14S1 } \\
\text { (deleted) } \\
\text { D14S20 } \\
\text { (deleted) }\end{array}$ & $>5.3 \mathrm{Mb}$ \\
\hline \multirow[t]{2}{*}{$14 q 32.31$} & & Ortigas et $a l^{17}$ & $46, X X, \operatorname{del}(14)(q 32.31)$ & $\begin{array}{l}\text { D14S308 } \\
(106175 \mathrm{~kb})\end{array}$ & - & $?$ \\
\hline & & $\begin{array}{l}\text { Van Karnebeek } \\
\text { et } a l^{19}\end{array}$ & $46, X X$, del(14)(q32.31 - qter) & $\begin{array}{l}\text { Complete set } \\
\text { human } \\
\text { subtelomeric } \\
\text { probes }\end{array}$ & $\begin{array}{l}\text { D14S985 } \\
\text { (100366 kb) } \\
\text { not deleted } \\
\text { D14S292 } \\
(103670 \mathrm{~kb}) \\
\text { deleted }\end{array}$ & $\begin{array}{l}2.3 \mathrm{Mb} \\
<\mathrm{X}- \\
<7.2 \mathrm{Mb}\end{array}$ \\
\hline \multirow[t]{3}{*}{$14 q 32.33$} & & $\begin{array}{l}\text { Schlade-Bartusiak } \\
\text { et al }{ }^{20} \text { (Patient } \\
\text { HSC1658) }\end{array}$ & $\begin{array}{l}46, \mathrm{XX} \text { deletion } \\
\text { diagnosed by FISH }\end{array}$ & $\begin{array}{l}\text { CKB }(103056- \\
103059 \mathrm{~kb}) \text { not } \\
\text { deleted, KNS2 } \\
(103165- \\
103247 \mathrm{~kb}) \\
\text { deleted }\end{array}$ & - & $>3.2 \mathrm{Mb}$ \\
\hline & Leube et $a l^{3}$ & & $\begin{array}{l}46, X X, \operatorname{der}(14) t(9 ; 14) \\
(q 34.3 ; q 32.33)\end{array}$ & - & - & $?$ \\
\hline & Maurin et $a l^{10}$ & & $\begin{array}{l}\text { 46,XX, der(14)t(14;D/ } \\
G)(q 32.33 ; p 12)\end{array}$ & $\begin{array}{l}\text { RP11-1087P8 } \\
\text { (not deleted) } \\
\text { RP11-417P24 } \\
\text { (deleted) }\end{array}$ & - & $1-1.6 \mathrm{Mb}$ \\
\hline $14 q ? \rightarrow 14 q$ ter & & Ravnan et $\left.a\right|^{21}$ & $\begin{array}{l}\text { Three patients: deletion } \\
\text { diagnosed by FISH }\end{array}$ & $\begin{array}{l}\text { Complete set } \\
\text { human } \\
\text { subtelomeric } \\
\text { probes }\end{array}$ & - & $?$ \\
\hline
\end{tabular}

phenotype assuming the absence of position effect, a total of eight cases with pure distal deletion were confirmed by FISH $^{12,17,19,20,21}$ and the break points were mapped in only four patients ${ }^{10,12,19,20}$ (Table 1).

We report here the clinical findings in two patients with $14 q 32.2$ and $14 q 32.32$ deletions identified by subtelomere screening. Patient 1 had a pure distal 14q32.2 deletion and patient 2 had a deleted derivative 14 chromosome from a paternal cryptic translocation $\mathrm{t}(14 ; 17)$ (q32.32; qter). We analysed by FISH the length of the corresponding size of the deletions to contribute to the del(14q) genotypephenotype correlation. The parental origin of the deletion in patient 1 was established by genotyping of sequence tagged sites (STS) microsatellites. This study has been initiated on behalf of the ACLF ('Association des Cytogeneticiens de langue Française'). 


\section{Subjects and methods}

Patients

Patient 1 This patient was the first child of nonconsanguineous Caucasian parents. His father and mother were aged 32 and 28 years, respectively, at the time of his birth. Prenatal ultrasound scans disclosed a thick nuchal skinfold at $11 \mathrm{WG}$, which prompted chorionic villi sampling (the result showed normal karyotype). Ultrasonography scans during second and third trimesters showed a short corpus callosum, and generalised oedema of the skin. A control karyotype on amniotic fluid cells was considered normal. The child was born at 40 weeks of gestation with a birth weight of $3450 \mathrm{~g}$ (50th centile), a length of $49.5 \mathrm{~cm}$ $(-1 \mathrm{SD})$, and $\mathrm{OFC}$ of $35 \mathrm{~cm}(\mathrm{M})$. Brief resuscitation was necessary because of primary apnoea. In the neonatal period, difficulty in swallowing necessitated transient G-tube feeding. At first evaluation at the genetic clinics at age 2 months, the following dysmorphic features were recorded: narrow face, bulging forehead, narrow and upslanted palpebral fissures, marked epicanthal folds, bushy eyebrows, cylindrical nose with wide, upturned tip and shallow root, long philtrum, narrow mouth, normal palate, microretrognathia, prominent, thick earlobes, short neck (Figure $1 \mathrm{a}$ and $\mathrm{b}$ ). The fontanels were widely opened.
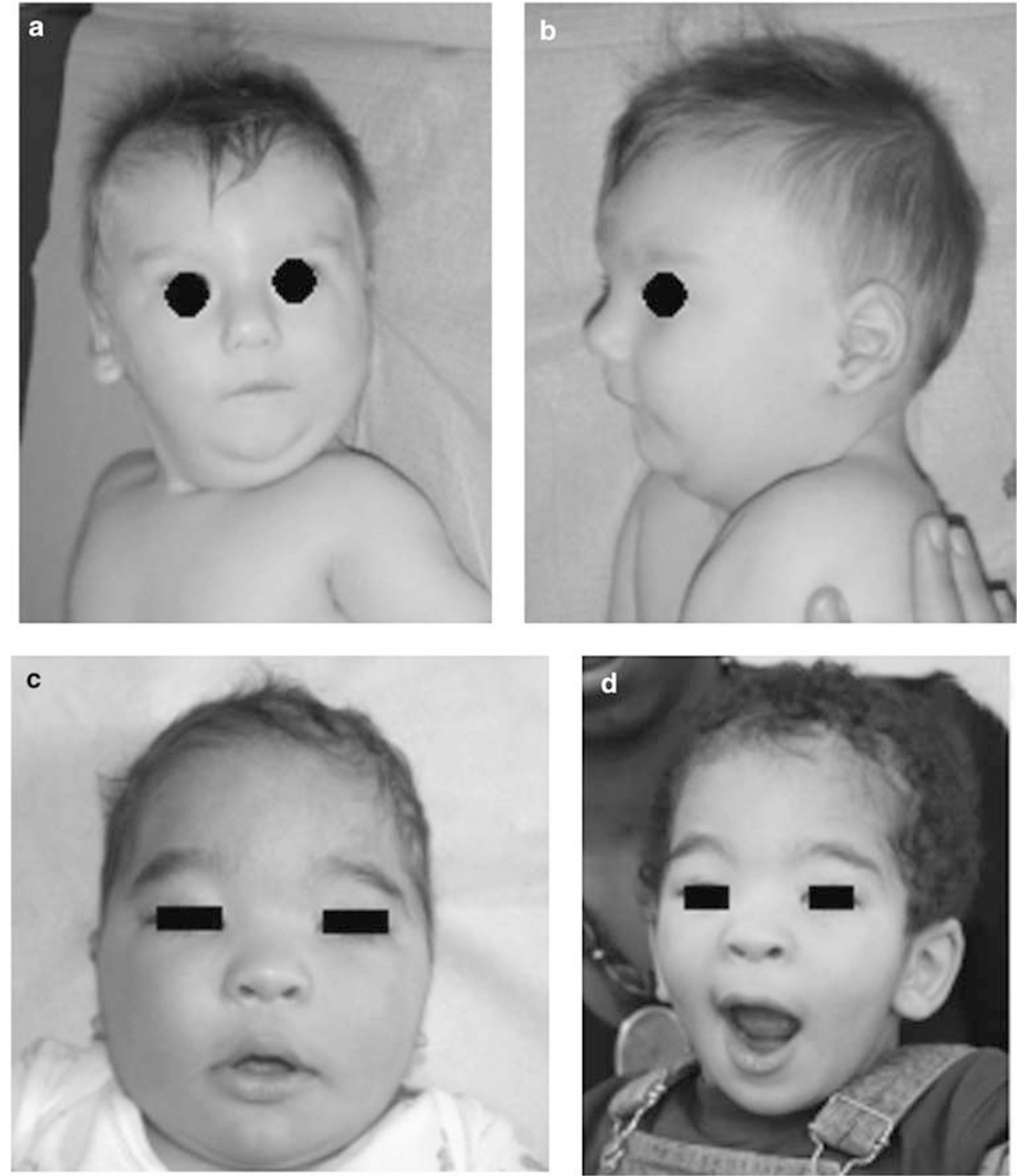

Figure 1 Pictures of patients 1 and 2 showing the dymorphic facial features. Patient 1 at 6 months of age: narrow face, bulging forehead, narrow, upslanted palpebral fissures, marked epicanthal folds, cylindrical nose with wide, upturned tip and shallow root, long philtrum, small mouth, microretrognathia (a) and prominent, thick earlobes (b). Patient 2 at 1 year (c) and 3 years (d) of age with hypertelorism, epicanthal folds, long philtrum, tented upper lip, long palpebral fissures, bilateral ptosis and forehead hirsutism (c and d). 
Genitalia were hypoplastic. The patient had gross hypotonia and poor mimics. Heart and kidney ultrasonography scans were normal and brain MRI confirmed the hypoplasia of the corpus callosum. Inguinal hernias were surgically corrected at age 3 months. Recurrent obstructive apnoea associated with gastro-oesophageal reflux required multiple hospital admissions. Psychomotor development was severely impaired: he sat with support at 10 months of age and without support at 2 years of age. The first spoken words were observed at 3 years of age but non-verbal skills were less affected (non-verbal communication, imitative plays). There was no hearing loss.

At the last examination, at 4 years of age, he was $100 \mathrm{~cm}$ tall (M), weighed $18.4 \mathrm{~kg}(+2 \mathrm{SD})$ and had an $\mathrm{OFC}$ of $50 \mathrm{~cm}$ $(-0.5 \mathrm{SD})$. The facial dysmorphism was quite the same as that recorded at the first examination but the forehead was more prominent and bulging, microretrognathia with overbite was more severe and the face was still hypomimic although no facial palsy was present. He was unable to walk. Neurological examination was otherwise unremarkable. His speech was limited to single, poorly understandable words.

Metabolic screening, creatine kinase and Steinert gene screening were normal. Systematic screening of subtelomeric regions disclosed a $14 \mathrm{q}$ deletion. No chromosomal rearrangement was found by FISH in the parents.

Patient 2 This boy was the first child of young healthy parents. Single thickening of nuchal skinfolds with increased translucency was found on ultrasonography at 12 weeks gestation. A karyotype, performed on amniotic fluid cells at 16 weeks of gestation, was considered normal $(46, \mathrm{XY})$. The boy was delivered at 40 weeks gestation. Birth weight, length and OFC were $3.170 \mathrm{~kg}$ (10th centile), $50 \mathrm{~cm}$ $(-1 \mathrm{SD})$ and $33.5 \mathrm{~cm}(-2 \mathrm{SD})$, respectively. Apgar score was normal. During the neonatal period, the boy was hypotonic and had coronal hypospadias, bilateral blepharophimosis and ptosis (surgically corrected at 10 months of age) and auricular septal defect, ostium secundum type. At age 6 months, he developed infantile spasms. Cortical atrophy and hypoplasia of the corpus callosum were evidenced on brain MRI. Blood karyotype and FISH for the Prader-Willi/ Angelman region were normal. The boy was clinically re-evaluated at the age of 3 years. OFC and weight decreased by -2 and $-1.5 \mathrm{SD}$, respectively, whereas height remained normal. Motor and mental developments were severely delayed. Facial dysmorphic features included hypertelorism, epicanthal folds, long palpebral fissures, bilateral ptosis, bushy eyebrows, long philtrum, tented upper lip, short neck and forehead hirsutism (Figure 1c and d). A multi-FISH analysis using a panel of subtelomeric probes was performed and led to the diagnosis of a cryptic terminal $14 \mathrm{q}$ deletion derived from a paternal cryptic $\mathrm{t}(14 ; 17)$ (qter;qter)pat translocation (data not shown).

\section{Methods}

Molecular cytogenetics Chromosome analysis was performed on peripheral blood lymphocytes by G- and R-banding using standard and 550-band resolution technique. FISH was performed on metaphase spreads obtained using previously described cytogenetic techniques. ${ }^{22}$ The terminal $14 \mathrm{q}$ deletion was diagnosed by subtelomeric FISH screening for both patients. The two deletions were further mapped by FISH with BAC and PAC probes chosen along the $14 \mathrm{q}$ arm from $97 \mathrm{Mb}$ to the telomere (end: $106368585 \mathrm{bp}$ ). The relative order of those probes was obtained by the NCBI and Ensembl databases (http://www.ncbi.nlm.nih.gov/mapview/, http://ensembl.org /Homo_sapiens/cytoview).

The following BAC clone probes provided by M Rocchi (Uniba-Bari) were used: RP11-300N18, RP11-483K13, RP11-68I8, RP11-431B1, RP11-168L7, RP11-796G6, RP111017G21, RP11-356L8, RP11-456M14, RP11-454M12 and RP11-435F10 from centromere to telomere, respectively. The most distal PAC clone GS-820M16 was provided by Knight $^{23}$ (Table 2). DNA from BAC and PAC colonies was extracted using the Macherey-Nagel kit (Nucleobond, 74579, Hoerdt, France) and labelled with Cy3-dUTP

Table 2 FISH results with BAC and PAC probes

\begin{tabular}{|c|c|c|c|c|c|}
\hline Chromosome 14 BACs/PACs & Position $(k b p)$ & NCBI end sequence & Ensembl & Patient 1 & Patient 2 \\
\hline RP11-300N18 & $93800-93944$ & AQ504718, AZ081941 & & Not del & - \\
\hline RP11-483K13 & $95325-95535$ & AQ637174, AZ303373 & & Not del & - \\
\hline RP11-6818 & $97837-98010$ & AL163760.4 & AL163760.4 & Not del & - \\
\hline RP11-431B1 & $98700-98770$ & AZ081948.2, AZ081949.2 & & Not del & - \\
\hline RP11-168L7 & $100860-101046$ & AZ517793.1 & & Del & - \\
\hline RP11-796G6 & $101187-101273$ & AQ500051.1 & AL355032.6 & Del & Not del \\
\hline RP11-1017G21 & $101408-101600$ & AL118558.6 & AL118558.6 & - & Not del \\
\hline RP11-356L8 & $101794-101966$ & AQ538229.1 & & - & Del \\
\hline RP11-456M14 & $102088-102275$ & AQ582808 & & - & Del \\
\hline RP11-454M12 & $102984-103176$ & AZ081843 & & - & Del \\
\hline RP11-435F10 & $104816-104967$ & AZ081951.2 & & Del & Del \\
\hline GS-820M16 & $>106166-106288<^{a}$ & & СТC-820M16 & Del & Del \\
\hline
\end{tabular}

ancluded in. 
Table 3 Genotyping results with STS markers

\begin{tabular}{|c|c|c|c|c|c|}
\hline \multicolumn{2}{|l|}{ STS } & \multirow{2}{*}{$\begin{array}{l}B p \\
37398001-37398204\end{array}$} & \multirow{2}{*}{$\begin{array}{l}\text { Father } \\
1 \text { and } 3\end{array}$} & \multirow{2}{*}{$\begin{array}{c}\text { Patient } 1 \\
1 \text { and } 2\end{array}$} & \multirow{2}{*}{$\begin{array}{l}\text { Mother } \\
2 \text { and } 4\end{array}$} \\
\hline D14S306 & $14 q 21.1$ & & & & \\
\hline D14S77 & $14 q 24.2$ & $72640306-72640535$ & 1 and 3 & 3 and 4 & 2 and 4 \\
\hline D14S308 & $14 \mathrm{q} 32.33$ & $106175186-106175506$ & 1 & 1 & 1 \\
\hline D14S1420 & $14 q 32.33$ & $106209174-106209361$ & - & - & - \\
\hline \multirow[t]{2}{*}{ Primers $1^{\mathrm{a}}$} & Left & TGTITGAAGAAGGGAGTCGT & 1 & 2 & 2 \\
\hline & Right & CCСACTCCATGTCTTCTGTT & - & - & - \\
\hline \multirow[t]{2}{*}{ Primers $2^{b}$} & Left & GTGCCTGTAGGTATCTATGC & 1 & 2 & 2 \\
\hline & Right & GСTСССТАTTTGCAAGATAC & - & - & - \\
\hline
\end{tabular}

${ }^{\text {a Sequence } 1 .}$.

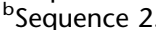

(Amersham Bioscience, PA53022, Gehealthcare, Europe Gmbh, Munich, Germany) by nick translation (Nick Translation System, 18160-010, Invitrogen, San Diego, CA, USA). The Cy3-labelled DNA probe was precipitated and hybridised using standard procedures. Twenty metaphases were analysed under a fluorescence DMRB microscope (Leica) equipped with Metasystem Isis software (Altlussheim, Germany).

Genotyping The DNA was extracted from peripheral blood lymphocytes using standard techniques for patient 1 and his parents. Genotyping of the DNA of the proband and his parents was performed by PCR amplification using STS microsatellite primers for STSs D14S306 (14q21.1), D14S77 (14q24.2), D14S308 (14q32.33) and D14S1420 (14q32.33). Two sequences (1 and 2) were tested for D14S1420 (Table 3). DNA was not available for patient 2 and his parents.

\section{Results}

\section{Molecular cytogenetics}

Patient 1 The deletion extended from a break point located between the undeleted clone RP11-431B1 and the deleted clone RP11-168L7 to the end of the chromosome $14 \mathrm{q}$ arm tagged by the most distal subtelomeric probe GS$820 \mathrm{M} 16$ (300 kb from the end of 14qter) (Table 2 and Figure $2 \mathrm{a}$ and $\mathrm{b})$. The deleted segment was shown to be $6.55 \pm 1.05 \mathrm{Mb}$ long (Ensembl cytoview database).

FISH results' designation: .ish $\operatorname{del}(14)(\mathrm{q} 32.2 \rightarrow$ qter $)$ (RP11-300N18+, RP11-483K13 + ,RP11-68I8 + ,RP11-431B1 + ,RP11-168L7-,RP11-796G6-,RP11-435F10-,GS-820M16-).

Patient 2 The deleted chromosome 14 was derived from a paternal cryptic translocation $\mathrm{t}(14 ; 17)$ (q32.32; qter)pat. The deletion extended from a break point located between the undeleted clone RP11-1017G21 and the deleted clone RP11-356L8, to the distal part of $14 \mathrm{q}$ arm (clone GS820M16) (Table 2 and Figure $2 c-f$ ). Its size was shown to be $4.67 \pm 0.10 \mathrm{Mb}$ long (Ensembl cytoview database).
FISH results' designation: .ish $\operatorname{del}(14)(\mathrm{q} 32.32 \rightarrow$ qter $)$ (RP11-796G6 + ,RP11-1017G21 + ,RP11-356L8-,RP11-456M14-, RP11-454M12-,RP11-435F10-,GS-820M16-).

\section{Genotyping}

Patient 1 This patient had inherited a maternal and a paternal allele for STS D14S306 and D14S77, but STS D14S308 was uninformative. No paternal allele was observed for D14S1420 sequences 1 and 2 (Figure 3). This analysis showed that the deleted chromosome 14 was of paternal origin (Table 3).

Patient 2 No DNA was available for the second family but nevertheless the derivative der(14) was derived from a paternal translocation. Consequently, we assumed this deleted chromosome 14 to be of paternal origin.

\section{Discussion}

Deletions on chromosome $14 \mathrm{q}$ are usually associated with ring chromosome $14 .^{1,24}$ A purely distal $14 \mathrm{q} 32$ deletion was reported in less than 15 published cases (Table 1), and only 8 of them were analysed by molecular cytogenetics (Table 1). The deleted fragments were mapped in only four cases. Indeed Schlade-Bartusiak et $a l^{20}$ described two patients with a terminal 14q32.3 deletion mapped by FISH using BAC clones. The first patient HSC1658 had a 3.2-Mblong $14 \mathrm{q} 32.3$ terminal deletion with a proximal break point located between $C K B$ and KNS2 genes. The second patient HSC1363, also studied by Wintle et al, ${ }^{12}$ had a 5.3Mb-long 14q32.3 terminal deletion with a proximal break point located proximally to the deleted gene DIO3. Maurin et $a l^{10}$ reported a third patient with a $\operatorname{der}(14) \mathrm{t}(14 ; \mathrm{D} /$ $\mathrm{G})(\mathrm{q} 32.33$;p12) resulting in a $1-1.6 \mathrm{Mb}$ terminal 14 q32.33 deletion with a break point located between non-deleted BAC RP11-1087P8 and deleted BAC RP11417P24. Van Karnebeek et $a l^{19}$ reported a fourth patient with a del(14)(q32.31) mapped by molecular analysis using PCR-based analysis of microsatellite repeat polymorphism $^{12,19,20}$ (Table 1). The deletion was shown to be truly 

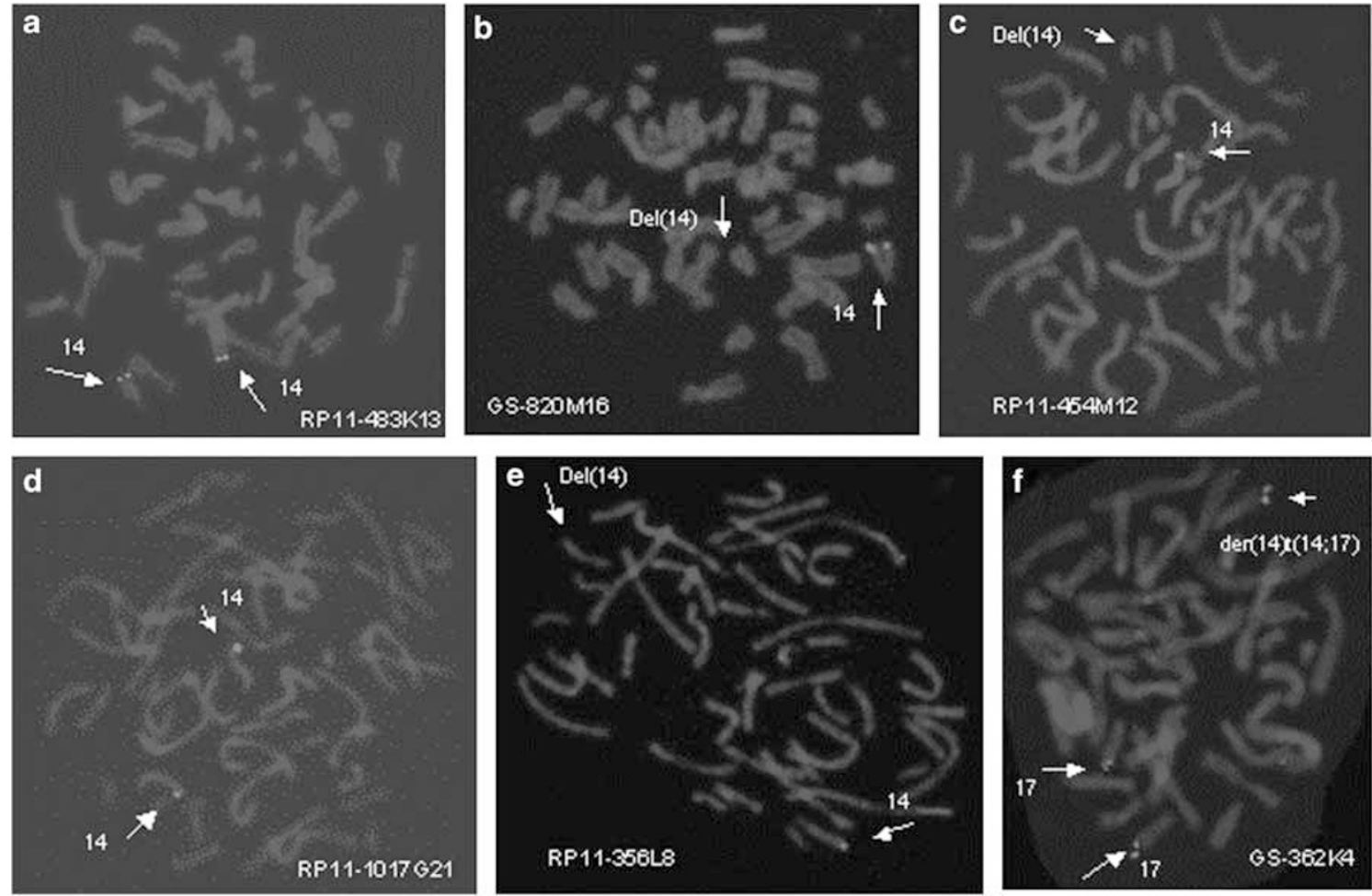

Figure 2 FISH using 14q32.3 BAC and PAC probes showed two red signals on chromosomes 14 when not deleted (probes RP11-483K13 (patient 1: a) and RP11-1017G21 (patient 2: d)) and a single red signal on its normal homologue when deleted for probes GS-820M16 (patient 1: b), RP11454M12 (patient 2: c) and RP11-356L8 (patient 2: e). FISH using chromosome 17q subtelomeric probe GS-362K4 (patient 2: f) showed three signals on both normal 17 chromosomes and one on the der(14)t(14;17)(qter;qter).

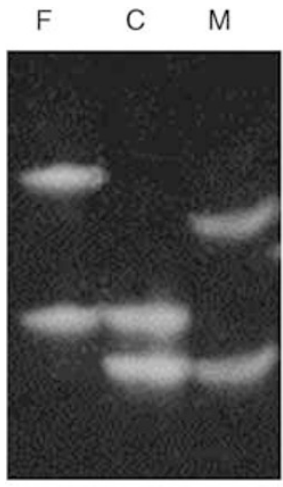

D14S77

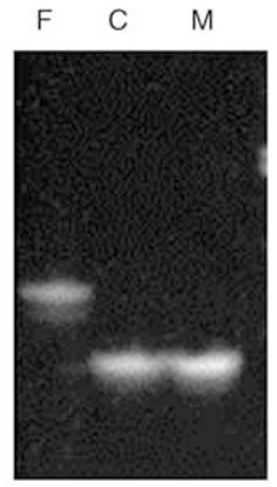

D14S1420
Figure 3 Migration pattern on the gels of amplified DNAs for patient no. $1(\mathrm{C})$, his father $(\mathrm{F})$ and mother $(\mathrm{M})$ using microsatellite markers STS D14S77 and D14S1420 (sequence 1: left primer TGTTTGAAGAAGGGAGTCGT/right primer CCCACTCCATGTCTTC TGTT). The child inherited both paternal and maternal alleles for D14S77 and only maternal allele for D14S1420.

telomeric and the proximal break point was located between D14S985 (not deleted) and D14S292 (deleted).

We report here two cases: patient 1 with a pure $\operatorname{del}(14)(\mathrm{q} 32.2) 6.55 \pm 1.05 \mathrm{Mb}$ long, and patient 2 with a distal $14 \mathrm{q} 32.32$ deletion $4.67 \pm 0.10 \mathrm{Mb}$ long derived from a $\mathrm{t}(14 ; 17)(\mathrm{q} 32.32$;qter)pat. Considering this last patient, we must keep in mind that the features were partially related to the cryptic 17qtel duplication. The following features associated with $17 \mathrm{q}$ partial distal trisomy were previously elicited: psychomotor and growth retardation, microcephaly, high forehead and temporal retraction, narrow palpebral fissures, large mouth with thin lips, cleft palate, low hairline, malformed ears, webbed short neck, abnormal skeletal features and external genitalia. ${ }^{25-27}$

Regarding the phenotype associated with terminal $14 \mathrm{q}$ deletions among 23 cases of deletions distal to 14q24, Van Karnebeek et $a l^{19}$ suggested to define the emerging phenotype by the features present in at least $50 \%$ of the cases such as neurologic deficits (mental retardation and hypotonia), a specific dysmorphic face (microcephaly, high and prominent forehead, blepharophimosis, epicanthi, broad and flat nasal bridge, short bulbous nose, broad philtrum, thin upper lip, small carpe-shaped mouth, highly arched palate, abnormal dentition, low-set ears with malformed helices and micrognathia) and a single palmar crease. Congenital malformations associated with such 14qter deletion were almost limited to congenital heart defects. Other rare anomalies were reported: haemangioma, coloboma, hypospadias, imperforate anus, 
fingerlike thumbs and oesophageal atresia with tracheooesophageal fistula, hearing loss and cat cry. ${ }^{19}$

Compared to the clinical criteria suggested by Van Karnebeek et $a l,{ }^{19}$ on a cohort of deletions distal to $14 \mathrm{q} 24$, we found some discrepancies. Patient 1 was not microcephalic and both patients 1 and 2 had neither highly arched palate nor abnormal dentition. Prominent earlobes instead of thick helices, short neck and single palmar creases were noted in both our patients and had not been previously reported. These patients were suspected initially at prenatal ultrasound screening because of the presence of thick nuchal skinfolds. Interestingly, both had hypoplasia of the corpus callosum. Brain morphological investigations have been documented in 11 patients with pure or not $14 \mathrm{q}$ terminal deletion in the literature, ${ }^{3,4,7-10,12,14,18,21}$ showing abnormalities in six patients. In one case, a subarachnoid haemorrhage over the cerebral convexity was observed at birth by CT scan, but the brain MRI was normal at 5 years of age. ${ }^{8}$ In a second case, postmortem examination showed irregular polygyria, lack of opercularisation of the temporal lobes, and occipital periventricular neuronal heterotopia. ${ }^{7}$ In a third case, MRI showed non-specific white matter hyperdensity in the periventricular areas ${ }^{10}$ and in a fourth case lissencephaly was reported. ${ }^{21}$ An abnormal corpus callosum was disclosed only in the two following cases: (a) Mertens et $a l^{18}$ reported a complete agenesis of the corpus callosum observed during autopsy of a newborn child associated with pure del(14)(q32) ${ }^{18}$ and (b) Bregant et al ${ }^{4}$ described a 2-week-old boy with asymmetric cranial lateral ventricles and hypoplastic corpus callosum associated with a $\operatorname{der}(14) \mathrm{t}(10 ; 14)(\mathrm{q} 24 ; \mathrm{q} 32)^{4}$. Unfortunately, the length of the deletion in the last two patients was not mapped as we did for our two patients with corpus callosum hypoplasia.

The delineation of a del(14)(q32) emerging phenotype is complicated by the fact that this region is submitted to imprinting. At least three imprinted genes have been reported in this region: MEG3 and DLK1 expressed maternally and paternally in humans, respectively ${ }^{28}$ and the gene DIO3 described as preferentially expressed from the paternal allele in the mouse fetus. ${ }^{29}$ The three documented $14 \mathrm{q} 32$ deletion data reported two maternally $^{19,20}$ and one paternally ${ }^{20}$ derived deletions. In the present observations, the loss of functionally active, paternally derived alleles, in combination with maternally imprinted genes, on $14 \mathrm{q}$ could be involved in the phenotype. Indeed patients 1 and 2 showed features observed in maternal uniparental disomy (UPD14) such as developmental deficiency, hypotonia, feeding problems and short stature. Patient 2 had a marked ptosis with long and narrow palbebral fissures. Interestingly, blepharophimosis was postulated to be characteristic for paternal UPD $14,{ }^{30}$ but none of the three genes MEG3, DLK1 and DIO3 were deleted in this patient. Regarding patient 1 ,
DIO3 was deleted but it could not be assessed if MEG3 or $D L K 1$ was deleted because these genes are located between the proximal and distal edge of the $14 \mathrm{q} 32.2$ break point: BACs RP11-431B1 (not deleted) and RP11-168L7 (deleted).

\section{Conclusion}

The number of reported cases with a terminal $14 \mathrm{q} 32$ deletion is very small. We report here two new cases with $\operatorname{del}(14)(\mathrm{q} 32.2)$ and $\operatorname{del}(14)(\mathrm{q} 32.32)$ of $6.55 \pm 1.05$ and $4.67 \pm 0.10 \mathrm{Mb}$, respectively, both on the paternal chromosome 14 . The patients had common postnatal features such as developmental deficiency, hypotonia, feeding problems, short stature, facial dysmorphic features and short webbed neck. We report two additional features that may help in prenatal diagnosis: thick nuchal skinfold and hypoplastic corpus callosum. Microcephaly usually reported in larger $\operatorname{del}(14 q)$ was not present in our two patients. These findings should contribute to delineate the emerging phenotype in terminal 14q32 deletion but need further data.

\section{Acknowledgements}

We are grateful to the patients and their families for their kind cooperation. We thank Dr M Rocchi for providing us with the $14 q \mathrm{BAC}$ clones from the Bari Resources for Molecular Cytogenetics. We thank $S$ Knight who provided us the reference PAC GS-820M16. We thank Dr $H$ Goldstein and $D r W V$ Bogomoletz for critical reading of the manuscript. This study was supported by the following grants:AOL 2001-2003 Reims CHU, Promotion: CHU-Bordeaux France, ACLF réseau télomère.

\section{Electronic-database information}

http://www.ncbi.nlm.nih.gov/mapview/; http://ensembl.org/Homo_ sapiens/cytoview

\section{References}

1 Schinzel A: A Catalogue of Unbalanced Chromosomal Aberrations in Man. Berlin, New York: Walter de Gruyter, 2001, pp 525-541.

2 Meschede D, Exeler R, Wittwer B, Horst J: Submicroscopic deletion in 14q32.3 through a de novo tandem translocation between 14q and 21p. Am J Med Genet 1998; 80: 443-447.

3 Leube B, Majewski F, Drechsler M, Royer-Pokora B: Unbalanced cryptic translocation $\operatorname{der}(14) \mathrm{t}(9 ; 14)(\mathrm{q} 34.3 ; \mathrm{q} 32.33)$ identified by subtelomeric FISH. Clin Dysmorphol 2003; 12: 261-265.

4 Bregant L, Gersak K, Veble A: Distal trisomy 10q/partial monosomy 14q: an unusual clinical picture. Genet Couns 2005; 16: $59-63$.

5 Uehara S, Akai Y, Takeyama Y et al: A case of a female infant with simultaneous occurrence of de novo terminal deletions on chromosome $14 \mathrm{q}$ and $20 \mathrm{p}$. Clin Genet 1993; 43: 28-33.

6 Nielsen J, Homma A, Rasmussen K, Ried E, Sorensen K, SaldanaGarcia P: Deletion $14 \mathrm{q}$ and pericentric inversion 14. J Med Genet 1978; 15: 236-238.

7 Masada CT, Olney AH, Fordyce R, Sanger WG: Partial deletion of $14 \mathrm{q}$ and partial duplication of $14 \mathrm{q}$ in sibs: testicular mosaicism 
for $\mathrm{t}(14 \mathrm{q} ; 14 \mathrm{q})$ as a common mechanism. Am J Med Genet 1989; 34: $528-534$.

8 Magnani I, Sacchi N, Darfler M, Nisson PE, Tornaghi R, FuhrmanConti AM: Identification of the chromosome 14 origin of a Cnegative marker associated with a $14 \mathrm{q} 32$ deletion by chromosome painting. Clin Genet 1993; 43: 180-185.

9 Chen CP, Chern SR, Lin SP et al: A paternally derived inverted duplication of distal $14 \mathrm{q}$ with a terminal $14 \mathrm{q}$ deletion. Am J Med Genet A 2005; 139: 146-150.

10 Maurin ML, Brisset S, Le Lorc'h M et al: Terminal 14q32.33 deletion: genotype-phenotype correlation. Am J Med Genet A 2006; 140: 2324-2329.

11 Hreidarsson SJ, Stamberg J: Distal monosomy 14 not associated with ring formation. J Med Genet 1983; 20: 147-149.

12 Wintle RF, Costa T, Haslam RH, Teshima IE, Cox DW: Molecular analysis redefines three human chromosome 14 deletions. Hum Genet 1995; 95: 495-500.

13 Miller BA, Jayakar P, Capo H: Child with multiple congenital anomalies and mosaicism 46, XX/46,XX, del (14)(q32.3). Am J Med Genet 1992; 44: 635-637.

14 Yen FS, Podruch PE, Weisskopf B: A terminal deletion (14)(q31.1) in a child with microcephaly, narrow palate, gingival hypertrophy, protuberant ears, and mild mental retardation. $J$ Med Genet 1989; 26: 130-133.

15 Telford N, Thomson DA, Griffiths MJ, Ilett S, Watt JL: Terminal deletion (14)(q32.3): a new case. J Med Genet 1990; 27: 261-263.

16 Wang HS, Allanson JE: A further case of terminal deletion (14)(q32.2) in a child with mild dysmorphic features. Ann Genet 1992; 35: 171-173.

17 Ortigas AP, Stein CK, Thomson LL, Hoo JJ: Delineation of 14q32.3 deletion syndrome. J Med Genet 1997; 34: 515-517.

18 Mertens DJ, De Die-Smulders CE, Kampschoer PH et al: 14q terminal deletion: prenatal diagnosis in a child with severe congenital anomalies. Genet Couns 2000; 11: 341-346.

19 Van Karnebeek CD, Quik S, Sluijter S, Hulsbeek MM, Hoovers JM, Hennekam RC: Further delineation of the chromosome 14q terminal deletion syndrome. Am J Med Genet 2002; 110: 65-72.
20 Schlade-Bartusiak K, Costa T, Summers AM, Nowaczyk MJ, Cox DW: FISH-mapping of telomeric 14q32 deletions: search for the cause of seizures. Am J Med Genet A 2005; 138: 218-224.

21 Ravnan JB, Tepperberg JH, Papenhausen P et al: Subtelomere FISH analysis of 11688 cases: an evaluation of the frequency and pattern of subtelomere rearrangements in individuals with developmental disabilities. J Med Genet 2006; 43: 478-489.

22 Dutrillaux B, Lejeune J: A new technic of analysis of the human karyotype. C R Acad Sci Hebd Seances Acad Sci D 1971; 272: 26382640.

23 Knight SJ, Lese CM, Precht KS et al: An optimized set of human telomere clones for studying telomere integrity and architecture. Am J Hum Genet 2000; 67: 320-332.

24 Howard PJ, Clark D, Dearlove J: Retinal/macular pigmentation in conjunction with ring 14 chromosome. Hum Genet 1988; 80: $140-142$.

25 Turleau C, De Grouchy J, Bouveret JP: Distal trisomy 17q. Clin Genet 1979; 16: 54-57.

26 Lenzini E, Leszl A, Artifoni L, Casellato R, Tenconi R, Baccichetti C: Partial duplication of 17 long arm. Ann Genet 1988; 31: 175-180.

27 Brisset C, Kasakyan S, L'Hermine AC et al: De novo monosomy 9p24.3-pter and trisomy 17q24.3-qter characterised by microarray comparative genomic hybridisation in a fetus with an increased nuchal translucency. Prenat Diagn 2006; 26: 206-213.

28 Murphy SK, Wylie AA, Coveler KJ et al: Epigenetic detection of human chromosome 14 uniparental disomy. Hum Mutat 2003; 22: $92-97$.

29 Hernandez A, Martinez ME, Fiering S, Galton VA, St Germain D: Type 3 deiodinase is critical for the maturation and function of the thyroid axis. J Clin Invest 2006; 116: 476-484.

30 Sutton VR, Coveler KJ, Lalani SR, Kashork CD, Shaffer LG: Subtelomeric FISH uncovers trisomy 14q32: lessons for imprinted regions, cryptic rearrangements and variant acrocentric short arms. Am J Med Genet 2002; 112: 23-27. 